Maxwell, Alexander. "Nemes, Robert. 2016. Another Hungary: The Nineteenth-Century Provinces in Eight Lives. Stanford: Stanford University Press. 292 p." Hungarian Cultural Studies. e-Journal of the American Hungarian Educators Association, Volume 9 (2016): http://ahea.pitt.edu DOI: 10.5195/ahea.2016.245

\title{
Nemes, Robert. 2016. Another Hungary: The Nineteenth-Century Provinces in Eight Lives. Stanford: Stanford University Press. 292 p.
}

\section{Reviewed by Alexander Maxwell, Victoria University of Wellington, New Zealand}

In his newest book, Robert Nemes examines the lives of eight individuals, six men and two women, whose lives spanned the long nineteenth century. The narrative proceeds in rough chronological order as each chapter covers a different person, identified in a chapter title by profession: "the journalist," "the rabbi," "the tobacconist," etc. The chapters provide a personal biography but situate the individual not only within his or her family life but also in a social context. Since the various people led quite different lives, each context in turn sheds insight into a different aspect of nineteenth-century Hungarian society. The results are fascinating.

Nemes presents his book as a "collective biography" $(3,10,234)$, and seeks an overall coherence with two main strategies. Firstly, Nemes frequently proposes cartographic metaphors: "mental maps" $(10)$, the "literary map" $(39,169)$, and most commonly "imagined geographies" $(40,66,91,105,119,131,167,180)$. Metaphorical cartography sometimes drives Nemes to unsubstantiated conjectures: discussing his "merchant," a figure known to history primarily through a surprisingly generous last will and testament, Nemes speculates that "if we imagine the 'map' that emerged from his life and work, it would be faded and creased from long years in the pocket of a peddler" (66). I found the device unhelpful.

Secondly, Nemes speculates about possible links between the different figures. When "the teacher" lands a teaching job in Miskolc, for example, Nemes notes that the father of the "the engineer" had once taught there as well (107). When Margit Kaffka, "the writer," sets a novel in Szatmár county, Nemes reminds the reader how the county had arisen in four previous chapters. Some of the connections seem strained, but the overall results are enlightening.

If the book's narrative, then, is somewhat disjointed, Nemes remains consistent in his theme: he has chosen individuals born in the north-eastern counties of the Kingdom of Hungary, now partitioned between the Hungarian Republic, Romania, Slovakia, and Ukraine. The introduction makes an interesting case for studying this particular region, not least the fact that it "does not have a strong identity" (5), at least in comparison to better-studied regions like Transylvania, Galicia, or Bohemia. Nemes defines his region mostly in terms of natural features, such as the Carpathians, the Tisza river, and its tributaries. Intriguingly, he takes no particular interest in the counties as such. Indeed, he shows such disinterest in administrative issues that he mistakenly describes the Soviet Union annexing Hungarian Carpathia at the 1920 treaty of Trianon (232), rather than the end of the Second World War. He instead investigates the imagined dichotomy between the metropolis and the provinces in the minds of his eight subjects, emphasizing the importance of provincial life in Hungarian imaginations. Nemes seeks to expand Hungarian history beyond Budapest, and while deftly describing the economic and cultural pull of Hungary's great capital, he always emphasizes local or provincial influences.

(cc) $\mathrm{Br}$

ULIS D-Serle
New articles in this journal are licensed under a Creative Commons Attribution 4.0 International License.

This journal is published by the University Library System of the University of Pittsburgh as part of its D-Scribe Digital Publishing Program and is cosponsored by the University of Pittsburgh Press 
Maxwell, Alexander. "Nemes, Robert. 2016. Another Hungary: The Nineteenth-Century Provinces in Eight Lives. Stanford: Stanford University Press. 292 p." Hungarian Cultural Studies. e-Journal of the American Hungarian Educators Association, Volume 9 (2016): http://ahea.pitt.edu DOI: 10.5195/ahea.2016.245

Just as Nemes looks away from the capital to the provinces, so does he shun the leading figures of Hungarian history to examine more obscure individuals. The eight people he discusses all attained sufficient prominence to leave a documentary paper trail, but the most famous names of nineteenth-century Hungarian history appear only in passing. István Széchenyi, the "greatest Hungarian," appears primarily as the patron of Pál Vásárhelyi, "the engineer" (73, 81-82). Sándor Petőfi, arguably Hungary's most famous poet, appears as an appreciative reader of poetry written by "the aristocrat" (38). Lajos Kossuth proves more difficult to ignore, yet repeatedly appears in the book as the recipient of a rabbi's blessing $(10,63,64)$. While the individuals studied often participated in public life, the book relegates high politics to the background.

The ethnic diversity of Northeastern Hungary enables Nemes to explore national conflict and anti-Semitism. Three of his eight subjects are Jewish who accommodate to the Hungarian state's nationalizing policies in different ways. The "journalist" is consciously Romanian, the "writer" a patriotic Hungarian. Since Roma, Rusyns, and Slovaks appear only in the background, the eight do not form a representative sample of either Hungary or the Upper Tisza region. Nevertheless, Nemes has fully digested recent literature on multiple loyalties and national indifference and sprinkles his prose with references to recent studies. Overall, he discusses the rise of nationalism with sophistication and sensitivity, particularly considering that he devotes his attention primarily to biography and provincial experiences. In his telling, patriotic mobilization appears less important than urbanization. In the opening chapters, provincial elites scorn the city's corrupt ways; in the final chapters provincial intellectuals flee to the city as a refuge of culture and modernity.

The great value of Another Hungary, however, lies in the detailed, engaging storytelling. Nemes is a solid scholar with the prose of a novelist. The eight people come memorably and vividly alive to the reader, and since they pursued different careers, the narrative as a whole illuminates many facets of Hungarian life. Each chapter is packed with informative details, but presented accessibly: the prose would be appropriate for undergraduates. The book is excellent, and a pleasure to read. 